\title{
Current Perspectives on Management of Type 2 Diabetes in Youth
}

\author{
Sachi Singhal ${ }^{1}$ (D) and Seema Kumar ${ }^{2, *(D)}$ \\ 1 Department of Internal Medicine, Crozer-Chester Medical Center, Upland, PA 19015, USA; \\ Sachi.Singhal@crozer.org \\ 2 Division of Pediatric Endocrinology, Mayo Clinic, Rochester, MN 55902, USA \\ * Correspondence: kumar.seema@mayo.edu; Tel.: +1-507-2842-3300; Fax: +1-507-284-0727
}

\section{check for}

updates

Citation: Singhal, S.; Kumar, S Current Perspectives on Management of Type 2 Diabetes in Youth. Children 2021, 8, 37. https://doi.org/10.3390/ children 8010037

Received: 1 December 2020 Accepted: 6 January 2021 Published: 10 January 2021

Publisher's Note: MDPI stays neutral with regard to jurisdictional clai$\mathrm{ms}$ in published maps and institutional affiliations.

Copyright: $(\odot 2021$ by the authors. Licensee MDPI, Basel, Switzerland. This article is an open access article distributed under the terms and conditions of the Creative Commons Attribution (CC BY) license (https:// creativecommons.org/licenses/by/ $4.0 /)$.

\begin{abstract}
The prevalence of type 2 diabetes mellitus (T2DM) in children and adolescents is on the rise, and the increase in prevalence of this disorder parallels the modern epidemic of childhood obesity worldwide. T2DM affects primarily post-pubertal adolescents from ethnic/racial minorities and those from socioeconomically disadvantaged backgrounds. Youth with T2DM often have additional cardiovascular risk factors at diagnosis. T2DM in youth is more progressive in comparison to adult onset T2DM and shows lower rates of response to pharmacotherapy and more rapid development of diabetes-related complications. Lifestyle modifications and metformin are recommended as the first-line treatment for youth with T2DM in the absence of significant hyperglycemia. Assessment of pancreatic autoimmunity is recommended in all youth who appear to have T2DM. Pharmacotherapeutic options for youth with T2DM are limited at this time. Liraglutide, a GLP-1 agonist, was recently approved for T2DM in adolescents 10 years of age and older. Several clinical trials are currently underway with youth with T2DM with medications that are approved for T2DM in adults. Bariatric surgery is associated with excellent rates of remission of T2DM in adolescents with severe obesity and should be considered in selected adolescents.
\end{abstract}

Keywords: type 2 diabetes mellitus; youth; adolescents

\section{Introduction}

The prevalence of childhood obesity is increasing globally, both in the developing and developed nations [1]. Obesity is a significant risk factor for type 2 diabetes and the increase in obesity has paralleled the increase in prevalence of type 2 diabetes (T2DM) [2]. In the SEARCH for Diabetes in Youth study in the United States, the unadjusted incidence rate of T2DM increased from 9.0 cases per 100,000 in 2002-2003 to 12.5 cases per 100,000 in 2011-2012 [3]. The adjusted relative annual increase of T2DM of $4.8 \%$ was highly significant. The SEARCH study also reported that the prevalence of T2DM in youth (defined as <20 years of age) increased by 30.5\% (95\% CI 17.3-45.1) between 2001 and 2009, after adjustment for case ascertainment [4]. T2DM disproportionately affects racial and ethnic minorities including Native Americans, Non-Hispanic Blacks, Hispanics, Asians, and Pacific Islanders [3,4]. Additionally, T2DM occurs in youth from disadvantaged backgrounds where multiple challenges to healthy lifestyle and adherence to medical recommendations often exist. Increase in the incidence of T2DM amongst children has been reported from other countries as well [5-7].

T2DM in youth differs from T2DM in adults with regard to the durability of glycemic control with lower rates of response to initial therapy such as lifestyle modifications and metformin [8-10]. Additionally, complications related to youth onset T2DM occur earlier than in adults and are often present at the time of diagnosis of diabetes [11-13]. Youth with T2DM also have other cardiovascular risk factors such as hypertension [11] and dyslipidemia [14] that further increase their risk for cardiovascular disease. 
T2DM in youth should be diagnosed using the criteria proposed by the American Diabetes Association (ADA) criteria [15]. Fasting plasma glucose (FPG) $\geq 126 \mathrm{mg} / \mathrm{dL}$ or $2-\mathrm{h}$ glucose concentration during an oral glucose tolerance test $\geq 200 \mathrm{mg} / \mathrm{dL}$ or hemoglobin A1C (A1C) $\geq 6.5 \%$ can be used as the criteria. The testing should be confirmed with a repeat test on a different day if the patient is asymptomatic. Random plasma glucose $\geq 200 \mathrm{mg} / \mathrm{dL}$ in a patient with symptoms of hyperglycemia is consider diagnostic of diabetes.

Current recommendations are to obtain pancreatic autoantibodies on all children in whom the diagnosis of T2DM is being considered as antibody-positive youth progress to insulin requirement more rapidly and are at risk for autoimmune disorders [16] (Figure 1). Additionally, due to the high prevalence of obesity in adolescents, the presence of overweight/obesity itself does not rule out type 1 diabetes. T2DM is extremely unlikely in prepubertal children. Testing for monogenic diabetes should also be considered in selected youth [15].

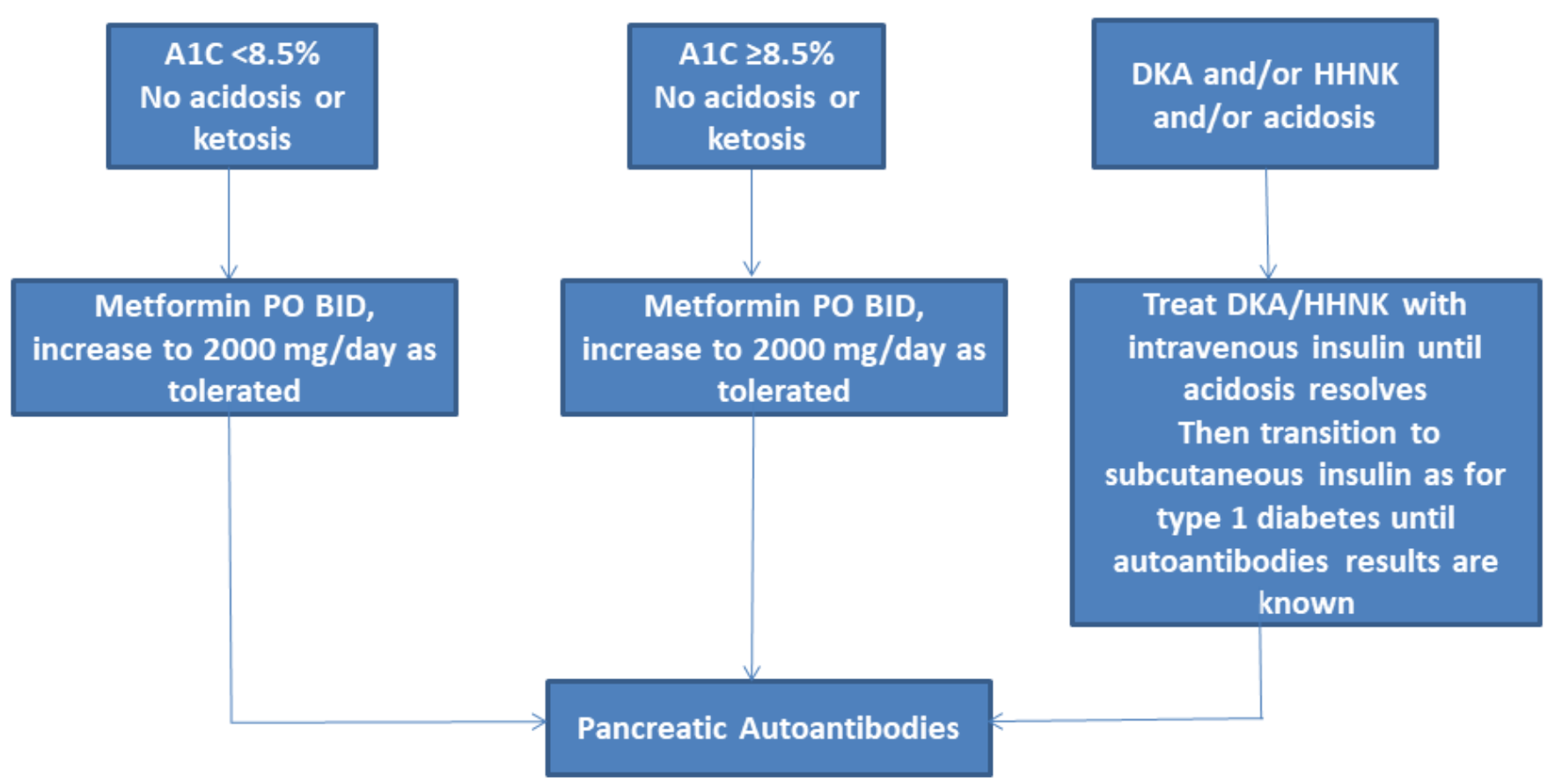

Figure 1. Initial management of new onset diabetes in youth with overweight or obesity. DKA, diabetic ketoacidosis; HHNK, hyperosmolar hyperglycemic nonketotic syndrome. Adapted from American Diabetes, A., 13. Children and Adolescents: Standards of Medical Care in Diabetes-2020. Diabetes Care 2020, 43 (Suppl. 1), S163-S182.

T2DM in youth should be managed by a multidisciplinary team consisting of a physician/other medical provider with expertise in diabetes, dietitian, nurse educator, mental health professional, and exercise specialists, if possible. The overarching goals of management of youth with T2DM are to achieve and subsequently maintain glycemic control, identify and manage associated comorbid conditions, and ultimately prevent microvascular and macrovascular complications of diabetes [15,17].

Glycemic Targets: A reasonable goal for most youth with T2DM is A1C less than $7 \%$ or FPG $<130 \mathrm{mg} / \mathrm{dL}$ [15]. However, more stringent goals such as less than $6.5 \%$ may be appropriate for selected individuals if the goal can be met without significant hypoglycemia or other adverse effects and in those with short duration of diabetes or patients who receive therapy with lifestyle or metformin only with significant weight improvement [15]. The lower target of $<6.5 \%$ in selected instances is supported by the evidence that hypoglycemia in patients with T2DM receiving insulin is rare [18] and A1C > $6.3 \%$ after 3 months of metformin or any increasing A1C even in the non-diabetes range was associated with increased risk for loss of glycemic control in the TODAY study [10]. 
The A1C targets should also be individualized based on baseline A1C at the time of diagnosis. Higher A1C targets in the short term might be appropriate for those that present with significantly elevated A1C at baseline. Self-monitoring of blood glucose needs to be individualized depending on the type of intervention for T2DM.

\section{Lifestyle Modifications}

Lifestyle modifications are recommended in all youth with T2DM at diagnosis [15,17] (Figure 1). The interventions should be provided with culturally and developmentally appropriate comprehensive lifestyle programs that integrate diabetes management with the ultimate goal of $7-10 \%$ reduction in body weight in those that have completed linear growth [15]. Weight loss of the magnitude of $0.5 \mathrm{~kg} / \mathrm{m}^{2}$ decrease in body mass index (BMI) [19] or a 0.25 to 0.5 decrease in BMI Z-score has been in children has been associated with improvements in insulin sensitivity [20].

Nutritional recommendations should focus on healthy eating patterns with an emphasis on the consumption of nutrient dense high-quality foods and decreased consumption of calorie-dense, nutrient poor foods $[15,21]$. Important strategies to facilitate these changes in eating habits include reduction in portion size, decreasing frequency of eating out, and replacing or eliminating high-calorie beverages such as sugar-containing drinks and juices with water or calorie-free beverages [22]. There is a lack of data on the effect of any specific type of dietary regimen on glycemic control in adolescents with T2DM. Data on the short-term or long-term efficacy of very low-calorie diets in this population is also minimal. In one study of 20 adolescent patients with T2DM, treatment with very low-calorie diets was associated with significant decrease in hemoglobin A1c from 8.8 to 7.4\% [23]. Pharmacological agents were discontinued in all but one of the 20 participants.

The physical activity goals for children and adolescents with T2DM are the same as those for youth in general [24]. Youth with T2DM should be encouraged to engage in moderate to vigorous physical activity for at least 30-60 min at least 5 days per week [25]. Examples of moderate activity include games such as baseball, catch and softball, hiking, brisk walking, and skateboarding. Examples of vigorous activities include games such as sports such as soccer, basketball, and ice or field hockey, jumping rope, and running. Resistance training (also called strength training) is recommended at least three times weekly. Resistance training can include muscle-strengthening activities such as weight lifting, push-ups, pull-ups, climbing ropes, and bone strengthening activities such as skipping, running, and jumping rope.

Both aerobic and resistance training improve insulin action by increasing glucose uptake by muscle [24]. A combination of aerobic and resistance exercise training may be more effective for glucose control than either type of exercise alone [26]. There are no data on the effect of resistance training on glycemic control in adolescents with T2DM but data in overweight and obese adolescents reveal improvement in insulin sensitivity with resistance training $[27,28]$. Twice per week resistance training in overweight Latino adolescents for a period of 12 weeks resulted in a significant improvement in insulin sensitivity relative to non-exercising adolescents in the control group [27]. The improvement in insulin sensitivity has been shown to be independent of changes in body composition $[27,28]$. Sedentary behavior should be decreased, and non-academic screen time such as computer, television, and video game should be restricted to less than $2 \mathrm{~h}$ daily [25]. Increase in physical activity has been shown to improve insulin sensitivity independent of its effect on body weight [29]. Additionally, exercise leads to improvement in cardiovascular risk factors, reduction in weight, and improvement in well-being [30]. Since many youth with T2DM may be sedentary at the time of diagnosis, assessment of physical activity at baseline and gradual increase to the target may be recommended to avoid musculoskeletal injury and improve adherence.

The TODAY study was a landmark study that enrolled 699 youth with T2DM who were between the ages 10 and 17. They had to have T2DM of less than 2 years duration and body mass index at or above the 85 th percentile. All participants had no evidence for 
pancreatic autoimmunity and were C-peptide positive. After a run in period of 2-6 months during which study subjects received metformin alone and standard diabetes education on healthy eating and exercise and achieved an A1C of less than 8\% [31], subjects were randomized to one of three arms, metformin alone, metformin plus insulin sensitizer rosiglitazone, or metformin plus intensive lifestyle intervention. The principal goal of the intensive lifestyle program in the study was to decrease percent overweight defined as BMI minus BMI at the 50th percentile for age and sex, divided by BMI at the 50th percentile times 100 by $\geq 7 \%$ through changes in eating and physical activity habits and to sustain those changes via ongoing treatment contact. The physical activity target for the intensive lifestyle program was 200 min per week of moderate-vigorous intensive activity for most participants and up to 300 min per week for those participants who entered the study already engaging in some regular, physical activity. The lifestyle intervention was delivered during face-to-face counseling sessions for the first 2 years [32]. The primary outcome was treatment failure or loss of glycemic control (defined as A1C $\geq 8 \%$ for at least 6 months or sustained metabolic decompensation requiring initiation of insulin for 3 months or more).

The rates of treatment failure were $51.7 \%$ with metformin alone, $46.6 \%$ with metformin plus intensive lifestyle intervention, and $38.6 \%$ with metformin plus rosiglitazone [33]. Therefore, lifestyle interventions did not confer an additional advantage in terms of glycemic control over metformin alone. Lifestyle intervention also did not confer an additional benefit in terms of weight loss, with $24.3 \%$ reaching weight loss target with metformin alone, $31.2 \%$ with metformin and intensive lifestyle intervention, and 16.7\% with metformin in combination with rosiglitazone [33]. The lack of additional benefit of intensive lifestyle intervention to metformin for both glycemic control and weight loss may be partly related to the low rate of attendance at lifestyle program visits with only half of the participants achieving the preplanned target of attending 75\% or more of the visits over a period of 2 years [33]. Multicomponent lifestyle interventions have been shown to have only modest weight loss effect in adolescents with severe obesity [34,35].

\section{Pharmacological Interventions}

\subsection{Metformin}

Current guidelines recommend the initiation of pharmacotherapy for children and adolescents at time of diagnosis of T2DM, along with intensive lifestyle management and diabetic education (Figure 1) [15]. Metformin is the preferred drug in youth that present with $\mathrm{A} 1 \mathrm{C}<8.5 \%$ and are in no acidosis or ketosis. Additionally, asymptomatic adolescents with $\mathrm{A} 1 \mathrm{C} \geq 8.5 \%$ may receive a trial of metformin if the provider anticipates adherence to lifestyle modifications. Metformin is a biguanide that decreases hepatic glucose production by inhibiting gluconeogenesis (Table 1) [36-38]. The effect on gluconeogenesis is mediated via the inhibition of a specific mitochondrial isoform of glycerophosphate dehydrogenase (mGPD), an enzyme responsible for converting glycerophosphate to dihydroxyacetone phosphate, thereby preventing glycerol from contributing to the gluconeogenic pathway. The inhibition of mGPD leads to an accumulation of cytoplasmic NADH and a reduced conversion of lactate to pyruvate, resulting in decreased lactate contribution to hepatic glucose production. This leads to a release of excess glycerol and lactate into the plasma.

In the TODAY study, almost half of the subjects (48.3\%) on metformin alone were able to maintain adequate glycemic control defined as $\mathrm{A} 1 \mathrm{C}<8 \%$ on metformin alone for up to 6 months [33]. In the half that did not achieve glycemic control on metformin alone, the median time to treatment failure was 11.8 months [33]. Therefore, the likelihood of youth requiring additional pharmacological treatment to meet glycemic controls was much higher than in adults. Metformin was not associated with any improvement in beta cell function with youth with T2DM, unlike in adults [16].

Metformin is associated with modest weight loss. In the TODAY trial, $24.3 \%$ of subjects on metformin alone reached the weight loss target (reduction of at least 7 percentage points in \% overweight defined as BMI minus BMI at the 50th percentile for age and sex, divided 
by BMI at the 50th percentile) and $31.2 \%$ of those on metformin and intensive lifestyle intervention reached the weight loss target [33].

Metformin should be started at a dose of 500-1000 mg per day and be gradually increased to a recommended therapeutic dose of $1000 \mathrm{mg}$ twice daily by escalating every 12 weeks. Metformin is associated with gastrointestinal side effects, and therefore, some patients may require slower dose escalation or may not be able to tolerate the maximum dose. Extended-release metformin preparations may have less frequent gastrointestinal side effects and are now currently available in tablet as well as in suspension form. These extended-release preparations are also beneficial for those who have difficulty complying with twice daily medications. Contraindications for metformin include hepatitis, renal insufficiency, cirrhosis, cardiopulmonary insufficiency, or alcoholism, as metformin can lead to lactic acidosis in the settings. The absorption of vitamin B12 and folic acid can be impaired in patients taking metformin. Therefore, adolescents taking metformin should be advised to take a daily multivitamin. All females with T2DM should be counseled regarding the need for birth control, as metformin can lead to the normalization of irregular menses and ovulatory cycles in females with polycystic ovary syndrome. Metformin should be discontinued $24 \mathrm{~h}$ before elective surgery and resumed $48 \mathrm{~h}$ after the procedure provided there are no complications.

\subsection{Liraglutide}

Glucagon-like peptide (GLP-1) is produced by the L cells of the small intestine and is secreted following the ingestion of nutrients. GLP-1 stimulates glucose-dependent insulin release from the pancreatic beta cells and inhibits post-meal glucagon release (Table 1) [39]. GLP-1 also has been shown to slow gastric emptying. Liraglutide is a GLP-1 analog that was approved by the Food and Drug Administration (FDA) and European Medicines Agency (EMA) in 2019 for children $\geq 10$ years and adolescents with T2DM. This approval was based on data from the recent ELLIPSE trial [40]. Similar to actions of endogenous GLP-1, liraglutide potentiates the post-prandial release of insulin, inhibits glucagon release, and increases satiety. GLP-1 analogs have been associated with modest weight loss in adolescents with obesity without T2DM [41,42]. In the ELLIPSE trial, 135 adolescents with T2DM between the ages of 10 and 16 years (mean age 14.6 years) who had glycated hemoglobin levels between 7 and $11 \%$ if they were being treated with diet or exercise alone or between 6.5 and $11 \%$ if they were being treated with metformin with or without insulin were randomized to subcutaneous liraglutide (up to $1.8 \mathrm{mg}$ daily) or placebo for 26 weeks plus metformin with or without basal insulin in combination with diet and exercise regimen [40]. At 26 weeks, the mean glycated hemoglobin decreased by 0.64 percentage points with liraglutide and rose by 0.42 percentage points with placebo (estimated treatment difference: -1.06 percentage points, $p<0.001$ ). By 52 weeks, estimated treatment difference had increased to -1.3 percentage points (decrease of -0.5 in liraglutide group and increase of 0.8 in the placebo group). Glycated hemoglobin levels of less than $7 \%$ were achieved in $63.7 \%$ of the patients in the liraglutide group as compared with $36.5 \%$ in the placebo group $(p<0.001)$. The fasting plasma glucose was lower by $1.08 \mathrm{mmol} / \mathrm{L}$ at 26 weeks and by $-1.03 \mathrm{mmol} / \mathrm{L}$ at 52 weeks in the liraglutide group and higher by $0.8 \mathrm{mmol} / \mathrm{L}$ at 26 weeks and by $0.78 \mathrm{mmol} / \mathrm{L}$ at 52 weeks in the placebo group. Both treatment arms had decreases in BMI, and the change in BMI z-score was not significantly different between the two groups (decrease by 0.25 at 6 months and by 0.34 at 52 weeks in the liraglutide group and decrease of 0.21 at 26 weeks and 0.16 at 52 weeks in the placebo group). The rate of adverse events per 1 patient-year of exposure was higher with liraglutide than with placebo due to a higher incidence of gastrointestinal adverse events, especially during the initial 8 weeks. Nausea was the most frequently reported adverse event. Hypoglycemic episodes and incidence of hypoglycemia were higher with liraglutide.

Current guidelines recommend considering liraglutide if glycemic targets are not met with metformin with or without basal insulin in children 10 years of age and older if they 
have no past medical history or family history of medullary carcinoma, multiple endocrine neoplasia type 2, or pancreatitis [25] (Figure 2). Liraglutide is started at a dose of $0.6 \mathrm{mg}$ subcutaneously once daily. The dose is increased by $0.6 \mathrm{mg}$ increments every $1-2$ weeks or longer until fasting glucose targets are achieved to a maximum of $1.8 \mathrm{mg}$ daily. Liraglutide has been noted to be associated with lower rates of adverse cardiovascular outcomes and the development and progression of diabetic kidney disease in adults with type 2 diabetes [43,44]. Currently, clinical trials are underway with other GLP-1 agonists for youth aged 10-17 years, dulaglutide (NCT02963766), and once weekly exenatide (NCT01554618).

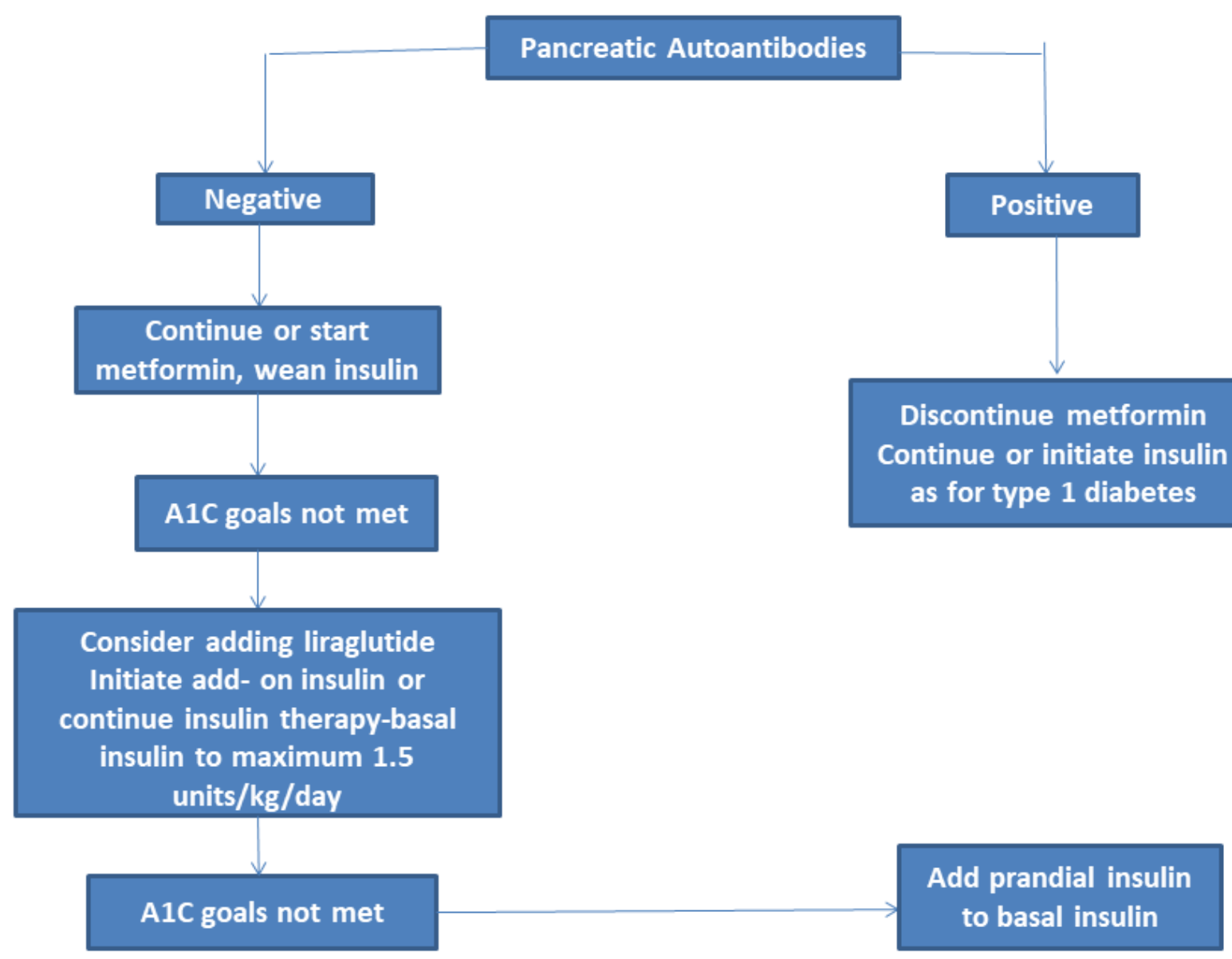

Figure 2. Goal-directed management of type 2 diabetes mellitus (T2DM) in youth. Adapted from American Diabetes, A., 13. Children and Adolescents: Standards of Medical Care in Diabetes-2020. Diabetes Care 2020, 43 (Suppl. 1), S163-S182.

\subsection{Thiazoledinediones}

Thiazolidinediones (TZDs) are agonists of peroxisome proliferator-activated receptors (PPARs), mostly PPAR-gamma that increase insulin sensitivity by their effect on adipose tissue and muscle to increase glucose utilization (Table 1) [45,46]. These drugs also decrease hepatic glucose production [46].

In the TODAY study, the metformin plus rosiglitazone arm had the lowest failure rate (loss of glycemic control defined as A1C $\geq 8 \%$ for at least 6 months or sustained metabolic decompensation leading to insulin use for three months or more) of $38.6 \%$ in comparison to metformin alone $(51.7 \%)$ and metformin plus lifestyle modifications (46.6\%) [33]. However, TZDs are not recommended for treatment of T2DM in youth, as the use of this class of medications was subsequently restricted by the FDA due to cardiovascular concerns with rosiglitazone [47], bladder cancer concerns with pioglitazone [48], and increased fracture risk concerns with both [49]. Other adverse effects noted include weight gain, fluid retention, and anemia. 


\subsection{Sulfonylureas}

Sulfonylureas stimulate the release of insulin from the pancreatic beta cells by interacting with the sulfonylurea receptor of the cells, thereby leading to inhibition of the adenosine triphosphate (ATP)-sensitive potassium channel (K-ATP channel) in the cells (Table 1) [50]. In a randomized trial (glimepiride versus metformin) in 285 youth with T2DM (mean age $13.8 \pm 2.3$ years and baseline A1C $8.5 \pm 1.58 \%$ ), participants receiving glimepiride (1-8 mg once daily) had a $0.54 \%$ reduction in $\mathrm{A} 1 \mathrm{C}$, and $42.4 \%$ of subjects in that group achieved $\mathrm{A} 1 \mathrm{C}<7 \%$ at 24 weeks [51]. The reduction in A1C in the glimepiride was similar to the group receiving metformin (500-1000 $\mathrm{mg}$ twice daily). However, weight gain was noted in the glimepiride group (BMI change $0.26 \mathrm{~kg} / \mathrm{m}^{2}$ for glimepiride versus $-0.33 \mathrm{~kg} / \mathrm{m}^{2}$ for metformin, $p=0.003$ ). There were no differences in the rate of hypoglycemia between the two groups.

\subsection{Dipeptidyl Peptidase-4 (DPP-4) Inhibitors}

Dipeptidyl peptidase-4 (DPP-4) is an enzyme that deactivates several bioactive peptides, including glucose-dependent insulinotropic polypeptide (GIP) and GLP-1. DPP-4 inhibitors act by prolonging the action of endogenous GLP-1 and GIP, translating in a glucoseappropriate increase in insulin secretion and suppression of glucagon release (Table 1) [52]. In a dose-finding study of linagliptin in 39 adolescents with T2DM, linagliptin use was associated with a dose-dependent decrease in A1C and fasting glucose [53]. The A1C reduction (compared to placebo) at 12 weeks from baseline was $0.48 \%$ and $0.63 \%$ with linagliptin $1 \mathrm{mg}$ and $5 \mathrm{mg}$ respectively. Reduction in mean fasting plasma glucose was 5.6 and $34.2 \mathrm{mg} / \mathrm{dL}$ in the $1 \mathrm{mg}$ and $5 \mathrm{mg}$ linagliptin groups, respectively. A phase 3 study (DINAMO)TM comparing linaglipin $5 \mathrm{mg}$ with SGLT2 inhibitor empagliflozin and placebo is ongoing (NCT 03429543). Side effects reported in adults with use of DPP-4 inhibitors include upper respiratory infection, headache, and hypersensitivity reactions [54]. No drug-related adverse effects were reported in the pediatric study [53]. Several trials in youth with T2DM with sitagliptin (NCT01760447, NCT01472367, and NCT01485614) have been recently completed, and another trial with alogliptin is ongoing (NCT02856113).

\subsection{Sodium-Glucose Co-Transporter 2 (SGLT2) Inhibitors}

Sodium-glucose co-transporter 2 (SGLT2) inhibitors mediate their effect by inhibiting the SGLT-2 present in the proximal collecting tubule of the nephron. These medications reduce the reabsorption of glucose and thereby increase urinary glucose excretion (Table 1). Glucosuria leads to an improvement in blood glucose levels and $\mathrm{A} 1 \mathrm{C}$ and reduction in weight [55]. In a single dose, open-label, randomized parallel group study in youth with T2DM aged 10-17 years with empagliflozin 5, 10, and $25 \mathrm{mg}$, exposure response relationships were noted to be similar between youth and adults after adjusting for significant covariates [56]. The drug was well tolerated with no adverse events, and one mild "dehydration" physician-reported event was reported in the small cohort [56]. In adults, reported adverse effects of SGLT2 inhibitors include vulvovaginal candidiasis, urinary tract infections, hypotension, and amputations [57]. SGLT2 inhibitors appear to increase the risk of diabetic ketoacidosis [58]. Many SGLT2 inhibitors have been shown to benefit cardiovascular and renal outcomes in adults with T2DM [59,60]. Currently, two clinical trials are studying other SGLT2 inhibitors in youth/young adults: ages 10-24; dapaglifozin (NCT02725593), and ages 10-17 years, canagliflozin (NCT03170518). Two ongoing clinical trials are examining the combination of DPP-4 inhibitors and SGLT2 inhibitors (linagliptin plus empagliflozin NCT03429543 and dapagliflozin plus saxagliptin NCT03199053) in youth with T2DM.

\subsection{Insulin}

The ADA guidelines recommend the initiation of insulin in youth that present with ketosis/ketonuria/ketoacidosis/hyperosmolar hyperglycemic non-ketotic syndrome or those with $\mathrm{A} 1 \mathrm{C} \geq 8.5 \%[15,17,25]$ (Figure 2). In these patients, subcutaneous or intravenous 
insulin should be initiated initially for the correction of hyperglycemia and metabolic abnormalities. Subcutaneous insulin should be continued and metformin can be started once the acidosis has resolved.

In youth that have A1C $\geq 8.5 \%$ without acidosis or ketosis, basal insulin is recommended at a starting dose of $0.25-0.5$ units $/ \mathrm{kg} /$ day, and the dose can be adjusted based on blood glucose values (Table 1). Long acting once-daily insulin preparations such as insulin glargine, detemir, or degludec can be started at bedtime. Metformin can also be started if acidosis or ketosis are not present.

The guidelines prior to the FDA approval of liraglutide for adolescents 10 and older with T2DM recommended that insulin should be considered if glycemic targets are not met within 4 months on metformin monotherapy [15,17]. However, liraglutide can now considered as an option in this scenario before starting insulin [25].

Multiple daily injections with prandial short-acting insulin should be recommended in youth on high doses of basal insulin (up to 1.5 units $/ \mathrm{kg}$ /day). Pancreatic autoantibodies are helpful in the management of diabetes in youth. If autoantibodies are positive, insulin therapy should be continued or initiated, and metformin should be discontinued (Figure 2). If pancreatic autoantibodies are negative, metformin should be continued or started, and an attempt should be made to wean insulin guided by self-monitoring of blood glucose (SMBG) values. Most (90\%) of the youth in the TODAY study with recent onset T2DM were able to be weaned off insulin and treated with metformin alone [31,61]. There is need for data on use of continuous glucose monitoring (CGM) in youth with T2DM that are on intensive insulin therapy [62]. In adults with T2DM, the use of CGM was associated with an improvement in A1C at 24 weeks compared to the control group [63]. Adverse effects related to insulin use include weight gain and hypoglycemia. Hypoglycemia is rare in youth with T2DM due to insulin resistance [18]. Insulin regimens should be carefully tailored to lifestyle and individual needs.

In conclusion, the initiation of metformin in conjunction with lifestyle interventions is recommended in all children with T2DM in the absence of acidosis/ketosis. Insulin therapy is recommended as the first line in those that present initially in diabetic ketoacidosis or hyperosmolar hyperglycemic nonketotic syndrome. Metformin can be added in those that were started on insulin initially after the resolution of acidosis/ketosis. Liraglutide and/or insulin should be considered as add-on second-line medications in youth that are not able to achieve optimal glycemic control on metformin alone. Ongoing trials are studying the effect of other GLP-1 analogs, SGLT2 inhibitors, and DPP-4 inhibitors in youth with T2DM. The results from these trials would expand the availability of pharmacological options for youth with T2DM in the near future. 
Table 1. Pharmacologic agents (Food and Drug Administration (FDA)-approved and off-label treatments for type 2 diabetes in children).

\begin{tabular}{|c|c|c|c|c|}
\hline Drug Name & Mechanism of Action & FDA Indication & Dose & Side Effects \\
\hline Metformin & $\begin{array}{l}\text { Increases insulin mediated glucose uptake in peripheral } \\
\text { tissues and decreases hepatic glucose production }\end{array}$ & $\mathrm{T} 2 \mathrm{DM} \geq 10$ years & $\begin{array}{l}\text { Start at } 500-1000 \mathrm{mg} \text { per day, } \\
\text { Increase to } 2000 \mathrm{mg} / \text { day in } \\
1-2 \text { divided doses }\end{array}$ & $\begin{array}{l}\text { Diarrhea, nausea, epigastric } \\
\text { discomfort, vomiting, } \\
\text { flatulence, B12 deficiency, } \\
\text { lactic acidosis }\end{array}$ \\
\hline Liraglutide & $\begin{array}{l}\text { Increases glucose-dependent insulin release from the } \\
\text { pancreatic beta cells and inhibits post-meal glucagon release, } \\
\text { also slows gastric emptying }\end{array}$ & $\mathrm{T} 2 \mathrm{DM} \geq 10$ years of age & $\begin{array}{l}\text { Start at } 0.6 \mathrm{mg} \\
\text { subcutaneously once daily. } \\
\text { Increase by } 0.6 \mathrm{mg} \text { increments } \\
\text { every } 1-2 \text { weeks or longer to } \\
\text { a maximum of } 1.8 \mathrm{mg} \text { daily }\end{array}$ & $\begin{array}{l}\text { Nausea, vomiting, abdominal } \\
\text { pain, diarrhea, potential } \\
\text { hypoglycemia }\end{array}$ \\
\hline Rosiglitazone & $\begin{array}{l}\text { Agonist of peroxisome proliferator-activated receptors } \\
\text { (PPARs), mostly PPAR gamma that increases insulin sensitivity } \\
\text { by its effect on adipose tissue and muscle to increase glucose } \\
\text { utilization; also decreases hepatic glucose production }\end{array}$ & Not approved in adolescents & $\begin{array}{l}\text { Start at } 2 \mathrm{mg} \text { twice daily, then } \\
\text { increase to } 4 \text { mg twice daily } \\
\text { after } 8 \text { weeks }\end{array}$ & $\begin{array}{l}\text { Weight gain, fluid retention, } \\
\text { decreased bone density, heart } \\
\text { failure, anemia }\end{array}$ \\
\hline Glimepiride & $\begin{array}{l}\text { Stimulation of insulin secretion via inhibition of the adenosine } \\
\text { triphosphate (ATP) sensitive potassium channel (K-ATP } \\
\text { channel) in the pancreatic beta cells }\end{array}$ & Not approved in adolescents & $\begin{array}{l}\text { Start at } 1 \mathrm{mg} \text { daily, can } \\
\text { increase in } 1-2 \mathrm{mg} \text { increments } \\
\text { to maximum of } 8 \mathrm{mg} \text { daily }\end{array}$ & Weight gain, hypoglycemia \\
\hline Empagliflozin & $\begin{array}{l}\text { Decreases reabsorption of glucose and thereby increases } \\
\text { urinary glucose excretion }\end{array}$ & Not approved in adolescents & $\begin{array}{l}\text { Dose in adults: start at } 10 \mathrm{mg} \\
\text { daily, can increase to } 25 \mathrm{mg} \\
\text { once daily after } 4-12 \text { weeks }\end{array}$ & $\begin{array}{l}\text { Vulvovaginal candidiasis, } \\
\text { urinary tract infections, } \\
\text { hypotension, risk of diabetic } \\
\text { ketoacidosis }\end{array}$ \\
\hline $\begin{array}{c}\text { Insulin: Basal (such as } \\
\text { Glargine, Detemir, Degludec) } \\
\text { and short acting (Aspart, } \\
\text { Lispro) }\end{array}$ & $\begin{array}{l}\text { Facilitates cellular uptake of glucose into myofibers and } \\
\text { adipocytes and stimulates GLUT4 translocation }\end{array}$ & $\begin{array}{l}\text { Approved for adolescents } \\
\text { with T2DM }\end{array}$ & $\begin{array}{l}\text { Basal insulin start at } 0.25-0.5 \\
\text { units } / \mathrm{kg} / \text { day and increase } \\
\text { based on blood glucose. Dose } \\
\text { of short acting is determined } \\
\text { by blood glucose values }\end{array}$ & $\begin{array}{c}\text { Hypoglycemia, weight gain, } \\
\text { hypertrophy/lipoatrophy at } \\
\text { injection site }\end{array}$ \\
\hline
\end{tabular}




\section{Metabolic Surgery}

Metabolic surgery should be considered for those adolescents with T2DM that have severe obesity (BMI $\geq 35 \mathrm{~kg} / \mathrm{m}^{2}$ ) and have uncontrolled glycemic control and/or serious comorbidities despite lifestyle and pharmacological interventions [15,17,22,25].

Bariatric surgery is highly effective in leading to remission or improvement in T2DM in youth with severe obesity [64-67]. Improvement in insulin sensitivity and improvement in beta cell function were noted following Roux-en-Y gastric bypass surgery in severely obese adolescents and young adults without diabetes [68]. In a study of 29 adolescents with severe obesity and T2DM enrolled in the Teen Longitudinal Assessment of Bariatric Surgery (TeenLABS) study who underwent Roux-en-Y gastric bypass or sleeve gastrectomy, remission of diabetes was noted in $95 \%$ of the patients at 3 years after the procedure [64]. Remission of pre-diabetes was noted in $76 \%$ of the cohort. Amongst a subset that had undergone Roux-en-Y gastric bypass surgery, an $84 \%$ reduction in the prevalence of T2DM was noted at a mean follow-up of 8 years (SD 1.6, range 5.4-12.5) [65]. A series of 108 patients between the ages of 5 through 21 years reported 91\% remission of diabetes and 100\% remission of prediabetes following laparoscopic sleeve gastrectomy [69]. The rates of remission of T2DM in adolescents were noted to be higher in adolescents than in adults $(86 \%$ vs. $53 \%$, risk ratio $1.27 ; 95 \%$ CI 1.03 to 1.57 ) despite no differences in percent weight change [70]. In another study, relapse of diabetes 5 years after laparoscopic sleeve gastrectomy was seen in $13 \%$ of diabetic adults, but none of the adolescents relapsed [67]. In a secondary analysis of data from severely obese adolescents that underwent surgical intervention (Teen-LABS, 30 subjects, mean age 16.9 [13] years) and medical interventions (TODAY consortia, 63 subjects, mean age 15.3 [13] years) over a period of two years, mean A1C decreased from $6.8 \%(95 \% \mathrm{CI}, 6.4-7.3 \%)$ to $5.5 \%$ (95\% CI, $4.7 \%$ to $6.3 \%)$ in Teen-LABS and went up from $6.4 \%(95 \% \mathrm{CI}, 6.1-6.7 \%)$ to $7.8 \%(95 \% \mathrm{CO}, 7.2-8.3 \%)$ in TODAY [71].

Bariatric surgery leads to significant weight loss and improvement in several cardiovascular risk factors in adolescents with severe obesity $[64,65,69,70,72]$. In the Teen-LABS study with 242 adolescents ( $n=161$ for Roux-en-Y gastric bypass and $n=67$ for sleeve gastrectomy), at 3 years after surgery, $27 \%$ weight loss ( $28 \%$ among those who underwent gastric bypass and $26 \%$ among those who underwent sleeve gastrectomy) was documented [64]. BMI reduction of $29.2 \%$ was noted at 5 years in 58 individuals undergoing RYGB [65]. Remission of elevated blood pressure was seen in $74 \%$ (95\% CI, 64 to 84 ), and remission of dyslipidemia in $66 \%$ (95\% CI, 57 to 74 ) at 3 years following surgery [64]. Significant improvements in blood pressure and lipids were also observed at mean follow up of 8 years in adolescents who underwent Roux-en-Y gastric bypass surgery [65].

Other eligibility criteria for bariatric surgery include the following: (a) History of previous sustained efforts to lose weight through changes in diet and physical activity; (b) Commitment from the patient and family to adhere to recommended pre- and postoperative treatments, including vitamin and mineral supplementation; and (c) Patient and family understanding of the risks and benefits of bariatric surgery [73,74].

The most recent expert guidelines do not recommend withholding surgery in those that have not completed puberty or physical maturity as determined by Tanner stage or skeletal maturation $[73,74]$. Contraindications for bariatric surgery include the following:

(1) Medically correctable cause of obesity;

(2) An ongoing substance abuse problem (within the preceding year);

(3) A medical, psychiatric, psychosocial, or cognitive condition that prevents adherence to postoperative dietary and medication regimens or impairs decisional capacity;

(4) Current or planned pregnancy within 12 to 18 months of the procedure; and

(5) Inability on the part of the patient or parent to comprehend the risks and benefits of the surgical procedure

Adolescents undergoing bariatric surgery need long-term monitoring, as long-term safety and efficacy data in this particular age group are limited [73,74]. Hypoferritinemia is the most common nutritional deficiency noted in adolescents following bariatric surgery in 
adolescents $[64,65]$. Other deficiencies include that of vitamin D, vitamin B12, folate, and vitamin A $[64,65]$.

\section{Assessment of Comorbid Conditions}

\subsection{Dyslipidemia}

Youth with T2DM often have dyslipidemia with elevated triglycerides, low highdensity lipoprotein cholesterol (HDL-C) and occasional high low-density lipoprotein cholesterol (LDL-C). In the TODAY study, $4.5 \%$ of participants were either receiving lipid-lowering therapy or had LDL-cholesterol $\geq 130 \mathrm{mg} / \mathrm{dL}$ at baseline, and this number increased over a period of 36 months to $10.7 \%$ [14]. Triglycerides $\geq 150 \mathrm{mg} / \mathrm{dL}$ were seen in $21 \%$ at baseline and increased to $23 \%$ over 36 months. The ADA recommendations suggest that lipid testing be performed at diagnosis of diabetes (but after glycemic control is well established) and annually thereafter [25]. Target lipid levels are LDL-C $<100 \mathrm{mg} / \mathrm{dL}$, HDL-C $>35 \mathrm{mg} / \mathrm{dL}$, and triglycerides $<150 \mathrm{mg} / \mathrm{dL}$.

\subsection{Hypertension}

Primary hypertension is prevalent in youth with T2DM. Hypertension was present in $12 \%$ of youth in the TODAY study at the time of enrollment and in $34 \%$ after an average follow up of 4 years [11]. Blood pressure should be checked at each health care visit, and the goal is $\mathrm{BP}<120 / 80 \mathrm{mmHg}$ or $<90$ th percentile in children younger than 13 years [25].

\subsection{Nonalcoholic Fatty Liver Disease}

Nonalcoholic fatty liver disease is common in children with T2DM and obesity [75]. Abdominal examination for hepatomegaly and measurement of serum alanine transferase (ALT) is recommended in youth with T2DM [25].

\section{Assessment of Complications}

Albuminuria, a sign of early diabetic nephropathy, is common among adolescents with T2DM at diagnosis, and the prevalence increases rapidly $[11,75,76]$. In the TODAY study, prevalence at baseline was $6 \%$ and increased to $18 \%$ by 5 years [77]. The urine albumin to creatinine ratio should be obtained at the time of diagnosis and annually. Physical examination should include detailed neurologic examination for neuropathy and should be performed at diagnosis and annually thereafter.

Patients should be screened for obstructive sleep apnea, depression/anxiety, eating disorders, and impairment of cognition at the time of diagnosis.

\section{Conclusions}

The prevalence of T2DM in children and adolescents is increasing due to the epidemic of childhood obesity. T2DM disproportionately affects children from ethnic minorities. Youth with T2DM often have additional cardiovascular risk factors. T2DM in youth is progressive and shows lower rates of response to oral pharmacotherapy than in adults. Lifestyle modifications and metformin are the recommended first-line treatment in children with T2DM in the absence of significant hyperglycemia. Pharmacotherapeutic options for youth with T2DM are limited at this time. However, several clinical trials with agents that are approved for adults are ongoing. Bariatric surgery is associated with excellent rates of remission of T2DM in adolescents and should be considered in selected adolescents with severe obesity.

Author Contributions: Conceptualization, S.S. and S.K.; methodology, S.S. and S.K.; software, S.S. and S.K.; validation, S.S. and S.K.; formal analysis, S.S. and S.K.; investigation, S.S. and S.K.; resources, S.K.; data curation, S.S. and S.K.; writing —original draft preparation, S.S. and S.K.; writing—review and editing, S.S. and S.K.; visualization, S.S. and S.K.; supervision, S.K.; project administration, S.K. Both authors have read and agreed to the published version of the manuscript.

Funding: This research received no external funding. 
Informed Consent Statement: Not applicable.

Conflicts of Interest: The authors declare no conflict of interest relevant to this manuscript.

\section{References}

1. Murtagh, Elaine, and NCD Risk Factor Collaboration. Worldwide trends in body-mass index, underweight, overweight, and obesity from 1975 to 2016: A pooled analysis of 2416 population-based measurement studies in 128.9 million children, adolescents, and adults. Lancet 2017, 390, 2627-2642. [CrossRef]

2. Mayer-Davis, E.J. Type 2 Diabetes in Youth: Epidemiology and Current Research toward Prevention and Treatment. J. Am. Diet. Assoc. 2008, 108, S45-S51. [CrossRef] [PubMed]

3. Mayer-Davis, E.J.; Lawrence, J.M.; Dabelea, D.; Divers, J.; Isom, S.; Dolan, L.; Imperatore, G.; Linder, B.; Marcovina, S.; Pettitt, D.J.; et al. Incidence Trends of Type 1 and Type 2 Diabetes among Youths, 2002-2012. N. Engl. J. Med. 2017, 376, 1419-1429. [CrossRef] [PubMed]

4. Dabelea, D.; Mayer-Davis, E.J.; Saydah, S.; Imperatore, G.; Linder, B.; Divers, J.; Bell, R.; Badaru, A.; Talton, J.W.; Crume, T.; et al. Prevalence of Type 1 and Type 2 Diabetes Among Children and Adolescents From 2001 to 2009. JAMA 2014, 311, 1778-1786. [CrossRef] [PubMed]

5. Pinhas-Hamiel, O.; Zeitler, P. The global spread of type 2 diabetes mellitus in children and adolescents. J. Pediatr. 2005, 146, 693-700. [CrossRef] [PubMed]

6. $\quad$ Likitmaskul, S.; Kiattisathavee, P.; Chaichanwatanakul, K.; Punnakanta, L.; Angsusingha, K.; Tuchinda, C. Increasing prevalence of type 2 diabetes mellitus in Thai children and adolescents associated with increasing prevalence of obesity. J. Pediatr. Endocrinol. Metab. 2003, 16, 71-78. [CrossRef]

7. Urakami, T.; Kubota, S.; Nitadori, Y.; Harada, K.; Owada, M.; Kitagawa, T. Annual Incidence and Clinical Characteristics of Type 2 Diabetes in Children as Detected by Urine Glucose Screening in the Tokyo Metropolitan Area. Diabetes Care 2005, 28, 1876-1881. [CrossRef]

8. Nadeau, K.J.; Anderson, B.J.; Berg, E.G.; Chiang, J.L.; Chou, H.; Copeland, K.C.; Hannon, T.S.; Huang, T.T.-K.; Lynch, J.L.; Powell, J.; et al. Youth-Onset Type 2 Diabetes Consensus Report: Current Status, Challenges, and Priorities. Diabetes Care 2016, 39, 1635-1642. [CrossRef]

9. Bacha, F.; Kim, J.Y.; Nasr, A.; Bacha, F.; Tfayli, H.; Lee, S.; Toledo, F.G.S. Insulin sensitivity across the lifespan from obese adolescents to obese adults with impaired glucose tolerance: Who is worse off? Pediatr. Diabetes 2017, 19, 205-211. [CrossRef]

10. Zeitler, P.; Hirst, K.; Copeland, K.C.; El Ghormli, L.; Katz, L.L.; Levitsky, L.L.; Linder, B.; McGuigan, P.; White, N.H.; Wilfley, D. HbA1cAfter a Short Period of Monotherapy With Metformin Identifies Durable Glycemic Control Among Adolescents With Type 2 Diabetes. Diabetes Care 2015, 38, 2285-2292. [CrossRef]

11. TODAY Study Group. Rapid rise in hypertension and nephropathy in youth with type 2 diabetes: The TODAY clinical trial. Diabetes Care 2013, 36, 1735-1741. [CrossRef] [PubMed]

12. Katz, L.E.L.; Bacha, F.; Gidding, S.S.; Weinstock, R.S.; El Ghormli, L.; Libman, I.; Nadeau, K.J.; Porter, K.; Marcovina, S.; McKay, S.; et al. Lipid Profiles, Inflammatory Markers, and Insulin Therapy in Youth with Type 2 Diabetes. J. Pediatr. 2018, 196, 208-216.e2. [CrossRef] [PubMed]

13. Magliano, D.J.; Sacre, J.W.; Harding, J.L.; Gregg, E.W.; Zimmet, P.Z.; Shaw, J.E. Young-onset type 2 diabetes mellitus-Implications for morbidity and mortality. Nat. Rev. Endocrinol. 2020, 16, 321-331. [CrossRef] [PubMed]

14. TODAY Study Group. Lipid and inflammatory cardiovascular risk worsens over 3 years in youth with type 2 diabetes: The TODAY clinical trial. Diabetes Care 2013, 36, 1758-1764. [CrossRef]

15. Bacha, F.; Bacha, F.; Grey, M.; Marcus, M.D.; White, N.H.; Zeitler, P. Evaluation and Management of Youth-Onset Type 2 Diabetes: A Position Statement by the American Diabetes Association. Diabetes Care 2018, 41, 2648-2668. [CrossRef]

16. Rice Consortium; Rice Consortium Investigators. Effects of Treatment of Impaired Glucose Tolerance or Recently Diagnosed Type 2 Diabetes With Metformin Alone or in Combination With Insulin Glargine on beta-Cell Function: Comparison of Responses In Youth And Adults. Diabetes 2019, 68, 1670-1680.

17. Zeitler, P.; Arslanian, S.; Fu, J.; Pinhas-Hamiel, O.; Reinehr, T.; Tandon, N.; Urakami, T.; Wong, J.; Maahs, D.M. ISPAD Clinical Practice Consensus Guidelines 2018: Type 2 diabetes mellitus in youth. Pediatr. Diabetes 2018, 19, 28-46. [CrossRef]

18. TODAY Study Group. Safety and tolerability of the treatment of youth-onset type 2 diabetes: The TODAY experience. Diabetes Care 2013, 36, 1765-1771. [CrossRef]

19. Reinehr, T.; Kiess, W.; Kapellen, T.; Andler, W. Insulin Sensitivity among Obese Children and Adolescents, According to Degree of Weight Loss. Pediatrics 2004, 114, 1569-1573. [CrossRef]

20. Reinehr, T.; Lass, N.; Toschke, C.; Rothermel, J.; Lanzinger, S.; Holl, R.W. Which Amount of BMI-SDS Reduction Is Necessary to Improve Cardiovascular Risk Factors in Overweight Children? J. Clin. Endocrinol. Metab. 2016, 101, 3171-3179. [CrossRef]

21. Barlow, S.E.; Expert Committee. Expert committee recommendations regarding the prevention, assessment, and treatment of child and adolescent overweight and obesity: Summary report. Pediatrics 2007, 120 (Suppl. 4), S164-S192. [CrossRef] [PubMed]

22. Styne, D.M.; Arslanian, S.A.; Connor, E.L.; Farooqi, I.S.; Murad, M.H.; Silverstein, J.H.; Yanovski, J.A. Pediatric ObesityAssessment, Treatment, and Prevention: An Endocrine Society Clinical Practice Guideline. J. Clin. Endocrinol. Metab. 2017, 102, 709-757. [CrossRef] [PubMed] 
23. Willi, S.M.; Martin, K.; Datko, F.M.; Brant, B.P. Treatment of Type 2 Diabetes in Childhood Using a Very-Low-Calorie Diet. Diabetes Care 2004, 27, 348-353. [CrossRef] [PubMed]

24. Colberg, S.R.; Sigal, R.J.; Yardley, J.E.; Riddell, M.C.; Dunstan, D.W.; Dempsey, P.C.; Horton, E.S.; Castorino, K.; Tate, D.F. Physical Activity/Exercise and Diabetes: A Position Statement of the American Diabetes Association. Diabetes Care 2016, 39, 2065-2079. [CrossRef]

25. American Diabetes Association. Children and Adolescents: Standards of Medical Care in Diabetes-2020. Diabetes Care 2020, 43 (Suppl. 1), S163-S182. [CrossRef]

26. Colberg, S.R.; Sigal, R.J.; Fernhall, B.; Regensteiner, J.G.; Blissmer, B.J.; Rubin, R.R.; Chasan-Taber, L.; Albright, A.L.; Braun, B. Exercise and type 2 diabetes: The American College of Sports Medicine and the American Diabetes Association: Joint position statement. Diabetes Care 2010, 33, e147-e167. [CrossRef]

27. Shaibi, G.Q.; Cruz, M.L.; Ball, G.D.; Weigensberg, M.J.; Salem, G.J.; Crespo, N.C.; Goran, M.I. Effects of Resistance Training on Insulin Sensitivity in Overweight Latino Adolescent Males. Med. Sci. Sports Exerc. 2006, 38, 1208-1215. [CrossRef]

28. Dias, I.; Farinatti, P.; Souza, M.D.G.C.D.; Manhanini, D.P.; Balthazar, E.; Dantas, D.L.S.; Pinto, E.H.D.A.; Bouskela, E.; KraemerAguiar, L.G. Effects of Resistance Training on Obese Adolescents. Med. Sci. Sports Exerc. 2015, 47, 2636-2644. [CrossRef]

29. Fedewa, M.V.; Gist, N.H.; Evans, E.M.; Dishman, R.K. Exercise and Insulin Resistance in Youth: A Meta-Analysis. Pediatr. 2013, 133, e163-e174. [CrossRef]

30. American Diabetes Association. Lifestyle Management: Standards of Medical Care in Diabetes_2018. Diabetes Care 2018, 41, S38-S50. [CrossRef]

31. Laffel, L.; Chang, N.; Grey, M.; Hale, D.; Higgins, L.; Hirst, K.; Izquierdo, R.; Larkin, M.; Macha, C.; Pham, T.; et al. Metformin monotherapy in youth with recent onset type 2 diabetes: Experience from the prerandomization run-in phase of the TODAY study. Pediatr. Diabetes 2012, 13, 369-375. [CrossRef] [PubMed]

32. TODAY Study Group. Design of a family-based lifestyle intervention for youth with type 2 diabetes: The TODAY study. Int. J. Obes. (Lond.) 2010, 34, 217-226. [CrossRef] [PubMed]

33. TODAY Study Group; Zeitler, P.; Hirst, K.; Pyle, L.; Linder, B.; Copeland, K.; Arslanian, S.; Cuttler, L.; Nathan, D.M.; Tollefsen, S.; et al. A clinical trial to maintain glycemic control in youth with type 2 diabetes. N. Engl. J. Med. 2012, 366, 22472256. [PubMed]

34. Kumar, S.; King, E.C.; Christison, A.L.; Kelly, A.S.; Ariza, A.J.; Borzutzky, C.; Cuda, S.; Kirk, S.; Abraham-Pratt, I.; Ali, L.; et al. Health Outcomes of Youth in Clinical Pediatric Weight Management Programs in POWER. J. Pediatr. 2019, 208, 5765.e4. [CrossRef] [PubMed]

35. Savoye, M.; Shaw, M.; Dziura, J.; Tamborlane, W.V.; Rose, P.; Guandalini, C.; Goldberg-Gell, R.; Burgert, T.S.; Cali, A.M.; Weiss, R.; et al. Effects of a weight management program on body composition and metabolic parameters in overweight children: A randomized controlled trial. JAMA 2007, 297, 2697-2704. [CrossRef] [PubMed]

36. DeFronzo, R.A.; Barzilai, N.; Simonson, D.C. Mechanism of Metformin Action in Obese and Lean Noninsulin-Dependent Diabetic Subjects. J. Clin. Endocrinol. Metab. 1991, 73, 1294-1301. [CrossRef]

37. Rena, G.; Hardie, D.G.; Pearson, E.R. The mechanisms of action of metformin. Diabetologia 2017, 60, 1577-1585. [CrossRef]

38. Pernicova, I.; Korbonits, M. Metformin-Mode of action and clinical implications for diabetes and cancer. Nat. Rev. Endocrinol. 2014, 10, 143-156. [CrossRef]

39. Lee, Y.-S.; Jun, H.-S. Anti-diabetic actions of glucagon-like peptide-1 on pancreatic beta-cells. Metabolism 2014, 63, 9-19. [CrossRef]

40. Tamborlane, W.V.; Barrientos-Pérez, M.; Fainberg, U.; Frimer-Larsen, H.; Hafez, M.; Hale, P.M.; Jalaludin, M.Y.; Kovarenko, M.; Libman, I.; Lynch, J.L.; et al. Liraglutide in Children and Adolescents with Type 2 Diabetes. N. Engl. J. Med. 2019, 381, 637-646. [CrossRef]

41. Kelly, A.S.; Rudser, K.D.; Nathan, B.M.; Fox, C.K.; Metzig, A.M.; Coombes, B.J.; Fitch, A.K.; Bomberg, E.M.; Abuzzahab, M.J. The effect of glucagon-like peptide-1 receptor agonist therapy on body mass index in adolescents with severe obesity: A randomized, placebo-controlled, clinical trial. JAMA Pediatr. 2013, 167, 355-360. [CrossRef] [PubMed]

42. Kelly, A.S.; Auerbach, P.; Barrientos-Perez, M.; Gies, I.; Hale, P.M.; Marcus, C.; Mastrandrea, L.D.; Prabhu, N.; Arslanian, S. A Randomized, Controlled Trial of Liraglutide for Adolescents with Obesity. N. Engl. J. Med. 2020, 382, 2117-2128. [CrossRef] [PubMed]

43. Marso, S.P.; Daniels, G.H.; Brown-Frandsen, K.; Kristensen, P.; Mann, J.F.; Nauck, M.A.; Nissen, S.E.; Pocock, S.; Poulter, N.R.; Ravn, L.S.; et al. Liraglutide and Cardiovascular Outcomes in Type 2 Diabetes. N. Engl. J. Med. 2016, 375, 311-322. [CrossRef] [PubMed]

44. Mann, J.F.; Ørsted, D.D.; Brown-Frandsen, K.; Marso, S.P.; Poulter, N.R.; Rasmussen, S.; Tornøe, K.; Zinman, B.; Buse, J.B. Liraglutide and Renal Outcomes in Type 2 Diabetes. N. Engl. J. Med. 2017, 377, 839-848. [CrossRef]

45. Hauner, H. The mode of action of thiazolidinediones. Diabetes Metab. Res. Rev. 2002, 18 (Suppl. 2), S10-S15. [CrossRef]

46. Petersen, K.F.; Krssak, M.; Inzucchi, S.; Cline, G.W.; Dufour, S.; Shulman, G.I. Mechanism of troglitazone action in type 2 diabetes. Diabetes 2000, 49, 827-831. [CrossRef]

47. Singh, S.; Loke, Y.K.; Furberg, C.D. Long-term risk of cardiovascular events with rosiglitazone: A meta-analysis. JAMA 2007, 298, 1189-1195. [CrossRef]

48. Tuccori, M.; Filion, K.B.; Yin, H.; Yu, O.H.; Platt, R.W.; Azoulay, L. Pioglitazone use and risk of bladder cancer: Population based cohort study. BMJ 2016, 352, i1541. [CrossRef] 
49. Home, P.D.; Pocock, S.J.; Beck-Nielsen, H.; Curtis, P.S.; Gomis, R.; Hanefeld, M.; Jones, N.P.; Komajda, M.; McMurray, J.J.V. Rosiglitazone evaluated for cardiovascular outcomes in oral agent combination therapy for type 2 diabetes (RECORD): A multicentre, randomised, open-label trial. Lancet 2009, 373, 2125-2135. [CrossRef]

50. Aguilar-Bryan, L.; Nichols, C.G.; Wechsler, S.W.; Clement, J.P.t.; Boyd, A.E., 3rd; Gonzalez, G.; Herrera-Sosa, H.; Nguy, K.; Bryan, J.; Nelson, D.A. Cloning of the beta cell high-affinity sulfonylurea receptor: A regulator of insulin secretion. Science 1995, 268, 423-426. [CrossRef]

51. Gottschalk, M.; Danne, T.; Vlajnic, A.; Cara, J.F. Glimepiride versus Metformin as Monotherapy in Pediatric Patients with Type 2 Diabetes: A randomized, single-blind comparative study. Diabetes Care 2007, 30, 790-794. [CrossRef] [PubMed]

52. DeMuth, H.-U.; McIntosh, C.H.; Pederson, R.A. Type 2 diabetes-Therapy with dipeptidyl peptidase IV inhibitors. Biochim. Biophys. Acta (BBA) Proteins Proteom. 2005, 1751, 33-44. [CrossRef] [PubMed]

53. Tamborlane, W.V.; Laffel, L.M.; Weill, J.; Gordat, M.; Neubacher, D.; Retlich, S.; Hettema, W.; Hoesl, C.E.; Kaspers, S.; Marquard, J. Randomized, double-blind, placebo-controlled dose-finding study of the dipeptidyl peptidase-4 inhibitor linagliptin in pediatric patients with type 2 diabetes. Pediatr. Diabetes 2017, 19, 640-648. [CrossRef] [PubMed]

54. Gooßen, K.; Gräber, S. Longer term safety of dipeptidyl peptidase-4 inhibitors in patients with type 2 diabetes mellitus: Systematic review and meta-analysis. Diabetes Obes. Metab. 2012, 14, 1061-1072. [CrossRef]

55. Clar, C.; Gill, J.A.; Court, R.; Waugh, N. Systematic review of SGLT2 receptor inhibitors in dual or triple therapy in type 2 diabetes. BMJ Open 2012, 2, e001007. [CrossRef]

56. Laffel, L.M.; Tamborlane, W.V.; Yver, A.; Simons, G.; Wu, J.; Nock, V.; Hobson, D.; Hughan, K.S.; Kaspers, S.; Marquard, J. Pharmacokinetic and pharmacodynamic profile of the sodium-glucose co-transporter-2 inhibitor empagliflozin in young people with Type 2 diabetes: A randomized trial. Diabet. Med. 2018, 35, 1096-1104. [CrossRef]

57. Musso, G.; Gambino, R.; Cassader, M.; Pagano, G. A novel approach to control hyperglycemia in type 2 diabetes: Sodium glucose co-transport (SGLT) inhibitors. Systematic review and meta-analysis of randomized trials. Ann. Med. 2011, 44, 375-393. [CrossRef]

58. Griffin, T.P.; Dinneen, S.F. SGLT2 inhibitors increase risk for diabetic ketoacidosis in type 2 diabetes. Ann. Intern. Med. 2020, 173, JC40. [CrossRef]

59. Zinman, B.; Wanner, C.; Lachin, J.M.; Fitchett, D.H.; Bluhmki, E.; Hantel, S.; Mattheus, M.; Devins, T.; Johansen, O.E.; Woerle, H.J.; et al. Empagliflozin, Cardiovascular Outcomes, and Mortality in Type 2 Diabetes. N. Engl. J. Med. 2015, 373, 2117-2128. [CrossRef]

60. Perkovic, V.; Jardine, M.J.; Neal, B.; Bompoint, S.; Heerspink, H.J.; Charytan, D.M.; Edwards, R.; Agarwal, R.; Bakris, G.; Bull, S.; et al. Canagliflozin and Renal Outcomes in Type 2 Diabetes and Nephropathy. N. Engl. J. Med. 2019, 380, 22952306. [CrossRef]

61. Kelsey, M.M.; Geffner, M.E.; Guandalini, C.; Pyle, L.; Tamborlane, W.V.; Zeitler, P.S.; White, N.H.; Treatment Options for Type 2 Diabetes in Adolescents and Youth (TODAY) Study Group. Presentation and effectiveness of early treatment of type 2 diabetes in youth: Lessons from the TODAY study. Pediatr. Diabetes 2016, 17, 212-221. [CrossRef] [PubMed]

62. Chan, C.L. Use of Continuous Glucose Monitoring in Youth-Onset Type 2 Diabetes. Curr. Diabetes Rep. 2017, 17, 66. [CrossRef] [PubMed]

63. Beck, R.W.; Riddlesworth, T.D.; Ruedy, K.; Ahmann, A.; Haller, S.; Kruger, D.; McGill, J.B.; Polonsky, W.; Price, D.; Aronoff, S.; et al. Continuous Glucose Monitoring Versus Usual Care in Patients With Type 2 Diabetes Receiving Multiple Daily Insulin Injections: A Randomized Trial. Ann. Intern. Med. 2017, 167, 365-374. [CrossRef] [PubMed]

64. Inge, T.H.; Courcoulas, A.P.; Jenkins, T.M.; Michalsky, M.P.; Helmrath, M.A.; Brandt, M.L.; Harmon, C.M.; Zeller, M.H.; Chen, M.K.; Xanthakos, S.A.; et al. Weight Loss and Health Status 3 Years after Bariatric Surgery in Adolescents. N. Engl. J. Med. 2016, 374, 113-123. [CrossRef] [PubMed]

65. Inge, T.H.; Jenkins, T.M.; Xanthakos, S.A.; Dixon, J.B.; Daniels, S.R.; Zeller, M.H.; Helmrath, M.A. Long-term outcomes of bariatric surgery in adolescents with severe obesity (FABS-5+): A prospective follow-up analysis. Lancet Diabetes Endocrinol. 2017, 5, 165-173. [CrossRef]

66. Inge, T.H.; Miyano, G.; Bean, J.; Helmrath, M.; Courcoulas, A.; Harmon, C.M.; Chen, M.K.; Wilson, K.; Daniels, S.R.; Garcia, V.F.; et al. Reversal of Type 2 Diabetes Mellitus and Improvements in Cardiovascular Risk Factors After Surgical Weight Loss in Adolescents. Pediatrics 2009, 123, 214-222. [CrossRef]

67. Khidir, N.; El-Matbouly, M.; Sargsyan, D.; Al-Kuwari, M.; Bashah, M.; Gagner, M. Five-year Outcomes of Laparoscopic Sleeve Gastrectomy: A Comparison Between Adults and Adolescents. Obes. Surg. 2018, 28, 2040-2045. [CrossRef]

68. Inge, T.H.; Prigeon, R.L.; Elder, D.A.; Jenkins, T.M.; Cohen, R.M.; Xanthakos, S.A.; Benoit, S.C.; Dolan, L.M.; Daniels, S.R.; D'Alessio, D.A. Insulin Sensitivity and beta-Cell Function Improve after Gastric Bypass in Severely Obese Adolescents. J. Pediatr. 2015, 167, 1042-1048.e1. [CrossRef]

69. Alqahtani, A.R.; Antonisamy, B.; Alamri, H.; Elahmedi, M.; Zimmerman, V.A. Laparoscopic Sleeve Gastrectomy in 108 Obese Children and Adolescents Aged 5 to 21 Years. Ann. Surg. 2012, 256, 266-273. [CrossRef]

70. Inge, T.H.; Courcoulas, A.P.; Jenkins, T.M.; Michalsky, M.P.; Brandt, M.L.; Xanthakos, S.A.; Dixon, J.B.; Harmon, C.M.; Chen, M.K.; Xie, C.; et al. Five-Year Outcomes of Gastric Bypass in Adolescents as Compared with Adults. N. Engl. J. Med. 2019, 380, 2136-2145. [CrossRef] 
71. Inge, T.H.; Laffel, L.M.; Jenkins, T.M.; Marcus, M.D.; Leibel, N.I.; Brandt, M.L.; Haymond, M.; Urbina, E.M.; Dolan, L.M.; Zeitler, P.S.; et al. Comparison of Surgical and Medical Therapy for Type 2 Diabetes in Severely Obese Adolescents. JAMA Pediatr. 2018, 172, 452-460. [CrossRef] [PubMed]

72. Michalsky, M.P.; Inge, T.H.; Jenkins, T.M.; Xie, C.; Courcoulas, A.; Helmrath, M.; Brandt, M.L.; Harmon, C.M.; Chen, M.; Dixon, J.B.; et al. Cardiovascular Risk Factors After Adolescent Bariatric Surgery. Pediatrics 2018, 141, e20172485. [CrossRef] [PubMed]

73. Armstrong, S.C.; Bolling, C.F.; Michalsky, M.P.; Reichard, K.W.; Section on Obesity, Section on Surgery. Pediatric Metabolic and Bariatric Surgery: Evidence, Barriers, and Best Practices. Pediatrics 2019, 144, e20193223. [CrossRef]

74. Pratt, J.S.A.; Browne, A.; Browne, N.T.; Bruzoni, M.; Cohen, M.; Desai, A.; Inge, T.; Linden, B.C.; Mattar, S.G.; Michalsky, M.; et al. ASMBS pediatric metabolic and bariatric surgery guidelines, 2018. Surg. Obes. Relat. Dis. 2018, 14, 882-901. [CrossRef]

75. Pinhas-Hamiel, O.; Zeitler, P. Acute and chronic complications of type 2 diabetes mellitus in children and adolescents. Lancet 2007, 369, 1823-1831. [CrossRef]

76. McGrath, N.; Parker, G.; Dawson, P. Early presentation of type 2 diabetes mellitus in young New Zealand Maori. Diabetes Res. Clin. Pr. 1999, 43, 205-209. [CrossRef]

77. Bjornstad, P.; Nehus, E.; El Ghormli, L.; Bacha, F.; Libman, I.M.; McKay, S.; Willi, S.M.; Laffel, L.; Arslanian, S.; Nadeau, K.J.; et al. Insulin Sensitivity and Diabetic Kidney Disease in Children and Adolescents With Type 2 Diabetes: An Observational Analysis of Data From the TODAY Clinical Trial. Am. J. Kidney Dis. 2018, 71, 65-74. [CrossRef] 